58959

R38 
Hollinger Corp. pH 8.5 


\section{The Use of the Gasoline Torch in Fighting Insects and Fungi}

Copyright, 19:3, by FRED REINLEIN.

Susanville, California

Circular No. 139

November 16,1913

On page 5 of my Circujar No. 138 the claim is made that 1 know of a practical way to stop the Argentine ant from nursing scale insects and plant lice on growing crops, and to control thein when they become a nuisance by insisting to live and multiply in some such place as a hollow tree near a house.

The answer is, I would apply heat under pressure as generated by a gasoline torch.

As near as I was ever able to learn, I was the first to use a gasoline torch as a means of insect control.

And as near as I was ever able to learn, I was the first to describu such use of a gasoline torch as a means of insect coṛtrol.

I first used a gasoline torch for insect control in the fall of 1896. I was engaged at that time at Mt. Vernon, Ill. in the growing, among other things, of plants of the cabbage tribe. The rainfall for severai years previous to 1896 had been greatly below normal, while the ternperature was above normal. One of the results was that the harlequin cabbage bug worked its way from the South up to and beyond Central Illinois; also the chinch bugs became very destructive to corn.

Being unable to find a satisfactory way of controlling the harlequin bug I at last hit upon using a gasoline torch such as is used $\because$ great deal by painters and plumbers and found that when used while the plants are in fresh condition, as in the morning, they stand enough heat to allow of the destruction of the bugs without suffering materially themselves. 
I realized that such us of heat under pressure is indefinitely cheaper and in many cases more practicable than the use of the sprays that were then advocated for the control of insects not amendable to the use of poison.

Thus leing directly interested in the control of some such insecis and realizing the possibility for the country at large, I went to work in the spring of 1907 to test the use of heat thus supplied on insects affecting various crops.

As the chinch bug was then very troublesome, corn received due attention. It was found that during cool spells all or most of the bigs would hide under the clods around the base of the plants, but by letting the blast from the torch play about the hase of the lowest leaves it was found that they would come tumbling out from the top of the leaf-sheaths and come in much gicater number from under the clods.

Now if a torch has such an effect upon insects hidden under clods, what must you expect if you let such a blast blow upon a nest o? Argentine ants when the ant chooses as far as possible decomposing vegetable matter. "......In summer time the ants apfear to do as litte excavating as possible and seem to limit their efforts to excluding light or water, ete." (Ent. Rull. No. 122. p. 56). "In wet situations or after heavy rains when the ground has become soaked with water the ants construct curious honey combed structures around the bases of tree trunks ....... falling in at the slightest touch....... the loose construction permitting a liberal circulation of air through the walls and ceilings."' (p. 56).

On the other hand: "In case of danger the workers' first instinct apnears to be to remove the young (eggs. larvae, nupae) to a place of safety and they readily sacrifice their own lives in order to accomplish this" (p. 40).

Thus imagine the blast from a torch blow upon such a pile and the queens and workers all coming out, the latter loaded 
with young and exposed at elose range to the blast emerging from the burner. It necessarily means annihilation of the whole outfit.

As to danger from fire: The country infested with New Orleans as a starting point has as per table 1, Ent. Bull. No. 122, a mean ancual precipitation of 54.9 inches. In such a country there is always enough growing vegetation to render fires over large areas next to impossible, except perhaps in the fall at the time of the falling of leaves. But in California where the ant is also present, in smaller numbers, the precipitation is only 16.2 inches, just one-third. And the rain comes mostly during the cool season. The drying up of vegetation begins in June. Ilence the fight must be done during the moist season and the time for using the torch would be a question for the legislature to consider and regulate.

During my tests in 1907 I found that if sweet corn is planted near cruciferous plants infested with the harlequin bug, many adults thy to it when it is tasseling and feed on the pollen during the warm part of the day. And I found that if you attempt to then kill them with a blast from the torch they will fly off. although part of them are likely to be slow enough to permit of scorching them. Now, of course, there is no need for a torch in this case, since it is easy to pick them off and throw them into a can with water and a little kerosene, and this, moreover, leaves rio bad effects upon the pollen. Thus by planting at frequent intervalls some hilis of sweet corn near where cruciferous plal:ts are to be grown, at least a large part of the adults can be secured throughont the season without the use of an insecticide at all.

But the effect of a blast upon harlequin bugs thus exposed serves as an additional illustration of how insects capable of considerable locomotion get a move on themselves as they feel the heat waves approach. This effect of the torch is of great 
value in the case of an insect like the boll weevil that emerges during a long period and which it may be desirable to pick off of the plants.

The bollweevil usually drops off of the plant when it is disturbed. And since I know that the heat vibrations frum a torch have a much more powerful effect than mere jarring in the case of the chinch bug and harlequin bug and in fact of all insects capable of ready locomotion, I don't see why it should not in the same manner affect the weevil.

Becanse of this I had in my Circular No. 18, June 1904 advised to use a torch,but this point was never investigated by the Bureau of Entomology.

At any rate it was then a secondary matter. The main question was whether traprows could be employed. The answer to that is yes and no, just what you understand under traprows and how you intend to manage them. If you examine the edge of the field daily for weevils as soon after as squares begin to set, this edge will serve as traprows and the reasons why this is a success you will find on page 7 of my Circular No. 137 and you also find there and on page 2 of my Circular No. 135 the reason; why any other use of traprows must be a failure. The Bureau of Entomology says nothing.

As the case now stands, the securing of hibernated adults whenever such is necessary or advisable. practicable at all only, according to my cldims, by a daily examination of the edge of the field for the rest of the period of emergence-a period of from 3 to 5 weeks-can be simplified by the use of a torch as by going along the edge of the field enough heat waves can be blown along the rows at a distance from the plants to not affect them at all unfavorably to make the weevils drop and thus ke readily noticed when by holding the burner close up to them for about 2 to 3 seconds this will kill then. But this use of : torch is rot an essential future of control. The essential 
poirt deseribed in detail May 18th 1912, in my Cireular No. 127, p. 4 is that while weevils when no squares are present settle upon the first cotton they come to, which with the field cleared by : plowing during the winter is the edge of the field, and then move only 0.35 foot per day, they with the advent of squares, begin feeding upon them exclusively and the males then will feed on the average upon one square for two days, while the females require a. least 5 times that many, that is, 3 per day. After thus feeding for 4 days upon squares the female is ready to oviposit, laying on the average 5 eggs per day, using a square for each, this being exclusive of what squares they require for feeding. Thus as every search for each additional square necessarily brings them further away from the edge of the field it becomes clear that successful control requires that their feeding upon squares must be stopped as soon as practicable after arrival and that, in order to reduce the movement, and cousequently the work of examining, to the minimum it is necessary to keep the squares at the edge as near as possible free of feeding punctures and as this can only be done by securing the weevils as soor after arrival as practicable it means that the edge of the field must be examined for arriving weevils daily till emergence is over, absolutely so or nearly so, as may seem best in practice.

If the Bureau of Entomology can figure it out some other way, let them do it.

I found in 1897 that in holding the troch up to most eggclusters such as of the harlequin bug on cabbage or of the squash bug on squash for about 2 to 3 seconds they get usually destroyed as far as hatching is concerned, and this amount of heat does little or no damage to the leaves especially when used in the morning whilu dew is on the plants. The thin, fragile leaves of plants of the eucumber tribe will be found to stard an astonishing amount of heat withuat injury. Then, 
again, whenever egg clusters like these were allowed to hatch, the young will stay together for some time and it takes but little of the blast to kill them, which is much faster than could be done by hand. If you will lift a cucumber or squash vine, big or small, carefully, for they do not like to be handled at al,, and you let the blast blow upon the ground just uncovered you will be surprised at the great number of insects you usually find thcre and these can be killed at close range while thus on the ground.

In handling plantlice, such as the cabbage or melon louse, the thing to do is to begin while infestation is slight and go along the rows at a slow pace, preferably in the morning, letting the blast blow onto the underside of the leaves, going up first one side of the row then down the other. This, repeated as may be necessary, will keep the pests in check without injuring the plants.

Some leafeating insects, as for instance blister beetles, are not readily killed by poison and work in numbers together. Such I have found can usually be succesfully handled with a torch.

By 1897 the San Jose Scale was getting a foothold in Illinois. I realized that such use of heat ought to be of value in controlling this insect and prove to be the cheapest means. Thus in the fall of $1897 \mathrm{I}$ went to an infested orchard and made a test.

And after getting a favorable report in the spring of 1898 I published my first book on the Use of the Gasoline Torch in Fighting Insects.

About three months after this I happened to notice in one of the hardware stores at Mt. Vernon, Ill. a gasoline torck bearing a label reading: Winfree Bug Exterminator.

Now, after due reflection, I concluded that the term Bug Ex. terminator when affixed to a gasoline torch was telling in one word the essence of what I had published on the use of the 
gasoline torch in fighting insects and was an infringment on my copyrighted matter, unless that word was used on such torches before I secured my copyright.

Mr. Winfree-J. M. Winfree, Nashville, Ill--according to a statement made to me in 1898 in writing, first used the torch in 1897 in an effort to control the chinch bug. He seemed to be backed by a concern interested in the making and selling of torches and some effort was made on his part to have me sell my copyright to him, but by that time I had already realized that the common plumbers torch is not the best type for that work, and that altogether the possibilities for the use of heat thus generated were greater than Mr. Winfree could see, hence nothing was accomplished.

I had realized that in using a common torch the operator has to sway the whole thing about, while, of course, only the burner was what really needed swaying. Then again when working on low plants the operator had to work in a stooping position. This suggested to me the need for a torch of the knapsack type. Noreover, as this torch was to be used also upon trees wherever there was any use for it, some arrangement had to be made that it might be suspended upon trees and be in a compact form when being moved from branch to branch.

At that time the browntail moth was making great headway in New England and since the most effective means of control then consisted in the cutting off, during winter, by means of pole shears, of the webs located usually at the ends of the branches, on trees of greatest hight as well as on smaller ones, I was satisfied that the use of such torch would be better all cround.

The torch also appeared to me to be of value in the case of a shade tree insect attacking fruit trees like the tussock moth the larvae of which are not readily controlled by poison and that deposits its cocoons largely in colonies and where the re- 
sulting females may, as they do in the case of the tussock moth, move but little from that place to deposit their eggs, since subjecting either the cocoons, or the adult females, which in the case of the tussock moth are wingless, or the resulting eggmasses to as much of a hot air blast as can be borne by that particular part of the tree, once or repeated as may be necessary, must be detrimental to the insect.

Also by that time I had realized, and published in various circulars, that heat thus applied licks off the fungus spores, the claim resting upon the fact that when the blast is applied when there is little or no sunlight, little particles upon the leaf can be seen to light up, and that it can be clearly seen during the day that leaves bearing masses of spores can be freed of these.

This firally resulted in the getting out on my part of a torch I began to make applications for Patent for in 1900 and had finally issue under No. 739,221, Sept. 15th, 1903. Its special features consist in that the pump is located in the center of the tank, the piston of the pump is worked by a handle having the shape of a hook, and this piston can be locked against movement by means of a pin, so that the torch can be suspended by means of the hook. A spur was provided on that hook to furnish a means of supporting the burner while the apparatus is heing moved from branch to branch. (See last page.)

A good many difficulties had to be overcome before satisfactory work could be secured from the apparatus. A tank of about two gallons was found to be handiest. To use the torch the tank is filled about one-third full of gasoline, the rest is left for compressed air.

About that time a party in Missouri advertised a torch for trapping insects at night. The apparatus consisted, in effect, of a pan containing water and some kerosene, upon which sat at right angles to each other two sheets of tin cut out at the junc- 
tion so that a common kerosene torch of the $10 \mathrm{c}$ type could burn. The sheets of tin were to serve the purpose of more reactily leading the insects to the flame to increase their chances of getting so injured that they might fall into the kerosene below.

Since the claims for that apparatus were extravagant the Cornell University, of Ithacca, N. Y. took the matter up, chiefly because they had years nefore made tests with a trap lantern, that is, a common lantern set upon a brick or bricks in a pan of water, with kerosene.

They found that they had caught practically the same run of insects with their lanteru as they did with the Missouri torch, except that in the case of lacewinged insects, the torch showed a much greater number of insects caught. They found they had caught nothing worth while, the injurious insects being offset by bencficial and neutral ones, the only thing worth mentioning being adults of the tent caterpillar, of which the specimens eaught were all or mostly males.

They, therefore, concluded that the use of traplights is of no value in a general way, but might be of value in the case of an injurious winged adult occurring in great numbers, flying only during a well defined and rather short period, and were both males and females are strongly attracted to light.

Now, there was at the outset anyway one insect that did fill the bill, to my knowledge. It was the browntail moth.

In as much as a gasoline torch generates a heat of about. 1500 edgrees and because of it, shows at night the burner to be red hot and gives off a yellowish flame in the shape of a blast, I realized that such a torch would be immensely more dangerous than could be either a kerosene torch or a trap lantern.

The fact that the Cornell people caught about the same kind of insects with the lantern as well as with the torch would tend to prove that the insects caught were not injured by any heat, 
but simply settled down upon the kerosene for a rest. And the exception in the case of the lacewings, of which about 3000 more were caught with the torch, tends to prove that this was due to an injury to their delicate wings by the flame of the torch, the heat not being strong enough to injure the other insects more than would the globe of a traplantern.

Since the Missouri party credited his torch with eatching codling moths the Cornell people paid close attention to what they caught of this insect and I believe they caught only two, by the combined and independent use of traplantern and torch. Another official entomologist, in Nebraska, I believe, caught with the Missouri torch 7 or 9 in one season. The Missouri man contended the codling moths are attracted to light and the Cornell people quoted Prof. E. D. Sanderson while he was with the Maryland Experiment Station as stating that he had liberated codling moths in a, room lighted by a Rochester lam!: and they flew around the lamp once or twice then retired to some corner and never came back. From this and from the statements of other investigators to the same effect Prof. Slingerland, who did the work, concluded the codling moth is not attracted to light.

Now, that is manifestly true as far as it goes. But I, rather accidently, can add the other half to the story. About May 22nd, 1904 I was working at Mt. Vernon, Ill. at about 9 p. m. on a desk near a window in the corner of a room having no screens and used a kerosene lamp that threw a good strong light upon my work sirce it had a common lamp shade of stiff paper, the rest of the room being nearly dark. Suddenly a moth flew in and began to fly about in a rapid zick-zack fashion within the lighted area for several seconds, then flew away. This at once reminded mo of the description of the codling moth flight as given in the Bulletin of the Cornell Universit; on this insect, but at tre sam time I recalled that all the Doc- 
tors had agreed that this moth is not attracted to light and as its flight was unusually rapid I did not feel inclined to attempt to citch it. However, when it came back the third time I concluded I had best try to get rid of it, and since it might be a ccdling moth, I was careful and accidently secured it in perfect condition. It was a codling moth. No mistake. I had raised codling moths from wormy apples and knew the insect. Then, further, I saved the specimen and had not long after a chance to show it to the Assistant of the State Entomologist of 1llinois. He said it was a codling moth. However, try it yourself.

Now, the cause-and there is always a cause-that Prof. Sanderson's moths did not hover about the light was, as near as I can see, that there was but little more light next to the white opaque globe that constitutes part of a Rochester lampto my knowledge-than there was away from it, while in my case the light was all confined to a small space.

The codling moth emerges during a long period in the spring. Then about 80 per cent of the worms try to enter at the calyx end of the young apple, which if it has previously been filled with arsenic by means of a spray, is as far as they go. Then, again, the second brood overlaps with the first. However, as the second brood cannot be handled with poison, the use of a suitable torch might prove to be of decided value in years when codling moths appear to be plentiful, if it is used occasionally during the early part of a quiet, warm and dark night away from any other lights.

The first time I used a gasoline torch for trapping insects was by letting the burner of a knapsack torch rest upon the edge of a galvanized iron washtub containing water with kerosene, the gasoline tank standing on the ground. After running about 2 hours I had about 1500 insects which were sent to Washington. Entomologist Howard had them examined. They 
proved to be mostly ground beetles-beneficial insects-not what was wanted.

In using a torch as thus described the gasoline supply is at a lower level than the burner. When the air pressure gets low, as it will when it is expected to run itself without attention, .he flow of gasoline becomes intermittent and the flame goes out ard the remaining gasoline is going to waste through th. biurner.

To avoid this I suspended the tank amply high to not only allow ot the burner to hang Jown, but to be then yet elevated from the ground as high as might be desired which with me usually was 3 to 5 feet.

It was found that under this arrangement there was always enough gravity pressure to secure a steady flow of gasoline till all was used up. A galvanized pail containing water with kerosene was huug onto the burner and as this did put altogether too much strain on the hose that connects the pipe carrying the burner with the tank, the pipe was at its upper end caught with a cord and the cord tied up at a length shorter than the hose, thus giving the required slack.

It soon became apparent that as far as catching qualities were concerned, this arrangement came pretty near being perfection.

Such a torch does not make a bright light. This in a way, is a disadrantage, since the light is seen over a smaller radius then is either that from a kerosene torch or a traplantern. On the other hand the insects that do fly to it cannot in the dariness about it correctly estimate the distance they are as yet away when making for it and ihey practically all bump their heads against the red hot burner or fly into the hot air blast blowing downwards into the pail. The rim of the pail is, or can be arranged to hang, about 2 or 3 inches below the mouth of the burner. The sides of the pail are much too hot for any in- 
sect if not at once completely stunned to get a holi on it. IJowever, observations seem to indicate that some of the stronger. and hardier beetles and, maybe, moths are not so stunned and often escape.

May beetles are a good sample of this class. These beetles when plentiful do great lamage. It may be that the females do a great deal less flying than the males after they become ireavy with eggs, but it is certain that light has attraction to them and there does not seem to be any reason why they should not iefore egg laying is wel! under way fly about as much as the males. In a general way both as beetles and grubs they are hard to get rid of economicaliy, hence in this and all similar cases light trapping ought to ba used for all it ean be made to do:

It would be quite feasible to take a disk of tin of the size of the pail, cut out a slot and then fit it in the shape of a low cone similar to a lamp shade just above the burner. This would leave a circle of light of about 4 inches for the insects through which to enter, while, once inside, the chances of ever getting out are very slim.

My tests in orchards showed a large variety of insects and in the truck garden there was noticed a good mixture of cucumber beetles and one eatch with the torch hung up among a row of young elm trees abou 25 feet high containcd an elm tree lierer, also one eatch examined by Prof. Slingerlard was reported to show a good many leaf hoppers, but on the whole there was no noticeable catch of any important insect in cuantity and the reason was there was no important insect about in quantity, nor could I devote as much time and money to earry on tests in different locations as I was willing to do.

I had fully realized by 1903 and stated so in one of the 16 circulars I published between 1898 and 1903 that this apparatus was sure to eatch larie quantities of browntail moths, as 
large catches then went, if, of course, located away from the electric lights. How to get rid of those and of other insects that stay within he influence of the electric lights is an independent problen. The browntail moth is on the wing, at its best, for 2 to \pm weeks and both male and female are strong flyers. The Depart. ment of Agriculture had bought a torch at that time, but they neither gave the involved system a fair trial during the day no: at night. On the whole, they condemned it.

Take the case of the nut weevils. At present, to my knowledge, the chiefmeans of control recommended is the destruction of the infested fallen fruits. Now, to my knowledge, most or all of these weevils are single brooded, the females are good flyers as else they could not oviposit their eggs to advantage and they have a well defined flying season. Why should not the torch be of value against the related apple and plum curculios, and, in a general way, against all night flying curculios affecting the various erops, since the use of poison is on the whell cut of question against this class of insects as is, practically, the use of contact insecticides.

Take the case of the elm tree borer. Their preferred feeding places are old or maturing elm groves. Why should a torch there not work to advantage? The same holds good with the hickory bark beetle.

Take the case of the pine destroying beetles: for all I know they are good flyers and they would be probably attracted to light. If so it ought to be possible to destroy enough of them by trapping to make unnecessary, to a large degree at least, the premature felling of trees affected by them.

The larch worm, according to Entomology Circular No. 125, p. 3 "has killed during several extensive outbreaks since. 1880 , from 50 to 100 per cent of the mature larch over vast areas in the north eastern United States and southeastern Canada'"... 
damage: "many billions of feet." Most likely the female adult is a good flyer and attracted to light.

In a general way these timber insects are good flyers and more likely to be attracted to light as not. The present chiet means of control is the felling and working up of the infested trees, many of which, if the attack could be reduced in severity, could be allowed to grow to maturity.

The larvae of the hawk moths and cut worms are often very numerous and destructive. The adults, of the eut worm at least, are attracted to light, and light trapping with a correct type of torch ought to be of at least some value. In my tests I caught a good many eut worm moths. Again, the mere ascertaining as to whether many or few such moths, or of May beetles, are around is of value, as this permits of taking cer:ain precautions by which if moths or beetles were plentiful, the damage from the resulting larvae, due to appear later, can be reduced.

In the case of the Argentine ant: "An enormous and general flight oi males and virgin queens was observed at Baton Rouge, La., in the spring of 1908 when large numbers of both sexes were captured in butterfly nets. On the other hand, during the spring of 1910 and that of 1911 no general flight was observed ...... Considerable numbers of males were seen flying around the eity electric lights..... but no queens were found with them.....'" (Ent. Bull. No. 122, p. 48). It would seem from the above that when the males and virgin queens do fly, part of them at least could be attracted to a traptorch. Unless a queen is thus destroyed soon after becoming adult and before she has commenced egglaying and shed her wings she is likely to live several years and can cever be fought with the toreh when it is used as a traplight.

On the other hand there is some tall use for a torch in other 
respects: "Nany permanent nests are located in the tops of trees, in rotten branches, or in places where borers or termites have been working"' (Ent. Bull. No. 122, p. 56). Whin in the past you found rests "within hollow trees, beneath the rough bark of growing trees, in forks of trees"' (p. 55) you have not known of a practical remedy. A hot air blast from a torch is: the only feasible thing, at least at present, and the torch ought to he of a type as was designed by me for work in trees.

Where the nests of this kind are permanent, in the sense of being perennial, some cold morning during the winter would he an especially good time for attack as then any ants falling off would freeze up.

Incidentally the torch is the best thing to set fire to the winter trap piles deseribed in my Circular No. 138.

When it comes to handling ants on growing crops you are killing two birds with one stone by using a torch. The aim, of course, is to apply heat enough to so injure the insects-the ants as well as their hosts, the scale and plant louse insectsas to fically suceumb to one or more applications without materially injuring the plant. Ants subjected to a blast while on a plant will quickly drop off and are then killed on the ground.

On page 77 of Ent. Bull. No. 122 the authors point out that experimests have shown that only about one per cent of workers are normally out on foraging trails and that therefore the killing off of these "does not materially affect the domestic economy of the colony or retard the rate of increase......"

Now according to my sustem of Argentine ant control as far is it is described in my (ircular No. 138 the opportunity for severest attack upon ther. consists in using winter trap piles and if this results in keeping both the ants and the scale and plant lice insects in check, nothing further need be done, but if these scale and plant lice insects are numerous, due or not due to any efforts on the part of the ants that may or may not 
be present, they have to be attended to and there is to my knowledge, during the growing season, all kinds of insects considered nothing more practicable than the judicions use of a hot air blast; and if ants are present, they get their dose of niedicine along with the rest. This would soon lead to a severe cecrease in the number of workers.

It is quite likely that the usual rate of about 99 per cent of workers remaining in the nest is conducive for securing the hest results and that any disturbance of this ratio has a tencency to make the queens join the foraging workers. "Queens will frequently leave the nests with the workers. Ten queens'egg laying machines', the business end of the colonywere collected in 30 minutes from a large trail of workers at New Orleans during January 1911. These were quite remote froun the nearest nest." Thus with the foraging detachment constantly cut down, queens are likely to go after a dose of medicine themselves. The thing to do is to let the blast blow along the trail.

The use of poison in the control of leaf eating insects is in a great many cases not practicable. The larvae of the cankerworm, the tussock moth, the browntail moth and the gipsy moth for instance can partake of considerable poison before they suceumb. Of the Cal:fornia tussock moth for instance you may read in Bulletin No. 183 of the California Experiment Station on page 203 "..... in laboratory experiments when the foliage was thoroughly covered with arsenate of lead applied at a dilution of 3 to 6 pounds to 50 gallons of water and newly hatched larvae were placed upon it, the majority of them died from arsenical poisoning, but even then some survived and only succumbed after prolonged exposure to thoroughly poisoned leaves. Slightly older insects were found to be extremely resistant; some survived four weeks when their only food was leaves literally whitewashed with arsenate of lead.." 
Then, again, many, probably most of these insects do not hatch all at nearly the same time and as many of them feed on the top of timber trees n. spray could well be applied and the spraying, if attempted, would usually have to be done in the spring when new foliage is constantly growing and rains are frequent. Then again while beetles as a whole may do great damage and are not readily affected by poison, this holds good in an especial manner in the case of snout beetles, such as the flum curculio and bollweevil, as these feed chiefly by lacerating the surface of the leaf or young fruit and feeding upon the tissues below.

If valuable trees, as for instance fruit trees, are affected with the larvae of the tussock moth or with the spring canker worm a moderate application of heat from a torch would make these insects drop, and would incidentally more or less injure them. This application of heat would incidentally be also sufficient to lick oft all or at least most of the fungus spores present also would affect any scale insects or lice that rilay be present and that would not be affected at all by an arsenical mixture.

Or take the case of thr pear thrips atecting various fruit trees and infesting the best fruit lands east of San Francisco. The adults emerge from the ground by the end of Februlur and during early March, force their way into the fruit buci, as soon as this is possible and feed upon the tenderest portions within. Eggs are deposited "just under the epidermis in t?.e fruit stems, young fruit ard leafstems" (Ent. Circ. No. 131, p. 5) hence cannot be attacked in anyway. But the larvae are on the trees in maximum numbers "from April 1st to 15th" an ideal time, in that climate, for any larvae to put in some busy days. The chief reliance to control the pear thrips is at present a "combination of distillate oil emulsion and the nicotine solution" (p. 8). The spray is admittedly expensive, the work has to he done with a power outfit giving a pressure of 150 to 200 
pounds and as the thrips may destroy all prospect of a crop in less than a week's time the use of the outfit is short. "Oniy" anglenozzles should be employed and these must be held close to the bud clusters to force the spray directly into the ends of the buds. This is absolutely necessary to secure good penetration and get satisfactory results......, (p. 20). Then why should not the use of heat, applied if necessary in the morning, destroy these adult thrips since they would be made to move about and the tender portions upon which they feed need not be subjected to a dangerous degree of heat? And why should it not destroy ¿little later the larvae?

Suppose some :ussock moth or canker worm larvae are present also. These upon feeling the blast would drop off before becoming fatally injured, which may hold good also with the thrips larvae, but usually all these larvae readily find their way back to the trunk, or else perish from lack of their food supply. As a means of following up the fight, soil should be ridged up against the trunk, drawn up from a circle of about 2 feet diameter with the periphery of this circle marked by a steep edge. T'he larvae will then drop in and as their ascent will be difficult and can bemade impossible altogether, they can be killed there by a blast from the torch.

This course is practicable in the case of larvae of the browntail moth and many other moths. The larvae of the gipsy moth feed at night and descenr on the trunk in the morning. If this same course is followed and the ridging is done roughly they will hide under the clods, this being their only choice as they rould not climb the steep wall at the periphery of the circlo and the application of a sharp heat blowing into the clods during the day will dispose of them.

Take the insects affecting the citrus fruits. While the scale insects can be kept in rheck by fumigation, the mealy bug, red 
spiders, mites and the white fly are but little affected by it, while the use of heat controls all of them at the same time.

The most important enemies of the hop plant are lice and red spiders. These ean be easily controlled by the use of heat, if the work is started early as it should be with any remedy in such cases.

The cotton stainer, at present, is the most important enemy of the cotton in Florida (Ent. Cire. No. 149. p. 1). Its life history and habits are similiar to that of the harlequin bug. It is easiest handled with the torch once it is inside the field.

The sprapevine has several important insect and fungus cremies. The insect enemies show a great variation in habits. Then, again, the fungus diseases require fighting in most cases. In the carly spring the flea beetle may be there to feed upon the buds of the vine, eafing them entirely away, or eating ont the centers. It is obvious, then, that because of this burrowing habit control by poison eannot be very satisfactory. If it is attempted at all, the best way to use it is to literally paint the huds with a thin paste of the poison mixture. The beetles are easily iarred from the viines and if you let a blast blow along the row they drop withont jarring and can be killed by a blast ciose $a_{\mathrm{u}}$ hand on the ground. Using a blast thus slightly would lick off the fungus spores that will be present. By the time the vines have developed any leaves the grapevine hoppers, having r,assed the winter as aduits, are ready to feed upon them. My tests showed me that this insect is amenable to treatment by the use of the torch. These hibernated adults should be gotten rid of lefore they start egg laying. This can be best dore by applying the blast during cool spells or in the morning when they are liable to be huddled together on the underside of the lcaves. If this is neglecter or only partly carried out, the work should be kept up while the resulting young have not yet acquired wings to any great extent as then their control beromes 
correspondingly more difficult. If the torch is used, however, this use of heat has always a tendency to lick the leaves clean of spores and also make such beetles as may be present, such as the adults of the graperoot worm or the click beetles, which are the adults of the wire worms, or of leaf chafers drop off the plant and thus be noticed and killed. Then, again, rather late in the season near when the grapes begin to ripen, the second broodi of the grape leaf folder is apt to appear in large numbers. Of the old methods of control the spraying of the leaves with poison before the worms hatch is the only means that has a chance of success, except, of course, crushing the larvae by hand later. The adult is a moth, probably night flying and attracted to light. The grape leaf hoppers seem to be also attracted to light to a limited extent, hence tests should be made as to what can be done with the trap torch to control these and other pests while in the adult stage.

A good illustration of how the means of insect control at present advocated by the Bureau of Entomology become impracticable when it comes to low priced crops-forest, cereal or forage-is given by the account of the ravages of the New Mexico range caterpillar in Entomology Bulletin No. 85, part $\mathrm{V}$. As to means of control the writer says on page 95 that the chief difficulty in applying remedial measures "is found in the extremely small value per acre of the grass crop" in these high and dry regions "lands rent for from 2 to 5 cents per acre for the year's pasturage......" (p. 95) with the land as now infested by the worms, with "the grass eaten to the very roots for miles....." and "the uneaten grass not relished by stock.....", (p. 61).

"This argument, which is a common one", that is, is just as apt to occur on other low priced cereal, forage or timber crops, "puts an end to all mechanical means of control of this pest 
(p. 96) by which the author means "by expensive means" ( $p$. 95.) "......no ready reiief is yet in sight" (p. 96).

The account sets forth that these caterpillars are the larvae of moths that begin to emerge about October 1st. "The great majority of the Hemileuca moths emerge from the pupae early in the morning....." (p. 82). "The freshly emerged moths remain perfectly quiet during the day......" (p. 82). "About $t: 0$ in the afternoon the male moths begin to stir..... very soon..... launches himself for his crepuscular flight" and "the female..... rarely takes to wing before $5 \mathrm{p}$. $\mathrm{m}$. She... . sails off in a straight jine..... many of the females fail to mate where they emerge....." (p. 83). "When fairly on the wing the flight of the Hemileuca moths is strong and persistent....." (p. 84). "How far the females travel carrying their eggs is largely a matter of conjecture, but as they fly at the rate of 8 to 10 miles an hour..... there seems good reason to believe that they traverse long distances before they alight.

The fluttering myriads of moths were present over very wide areas..... Taking into account the fact that the life of the individual moth rarely if ever exceeds three days, the successive multitudes......constitute a menace..... that needs only to be seen to be appreciated" (p. 85) "When attracted to a lighted window at night the moths remain there....." (p. 88) .. ...multitudes of Hemileuca moths......were flying about the electric lights at Trinidad, Colo......" (p. 62) which tends to show, strongly, that light has a great deal of attraction to the moths.

Well, it is by the use of a trap torch ehiefly that some ready relief is coming into sight. There is no gocd reason why with a torch hung up myriads of moths shculd rot come witrin its influence each night, although moonshine may act unfavorahly. There is no good reason why not at least a substantial 
percentage can be thus destroyed. Since "the males are much more active than the females".... (p. 84), more males than females must be expected to be caught. Catching males, especially as they constitute about 3-5 of the total number, may seem to te useless, but indications are that a male can serve only three females during his life of three days, that is, is capable only of rating with one female in a night. If so the destruction of the males would not be useless, because many females would fail to find mates and lay sterile eggs. Or with a searcity of males would do more flying.

"The usual time for depositing the eggs is in the early part of the day....."' (p. 69). Hence a female must have been fiying at least one night, acd there is a probability that she does not oviposit till after the second night. It is also not likely that the females after ovipositing do much more fiying. Hence a torch will be practically always dangerous to them, and their offspring, when on the wing.

A trap lantern hung up 5 feet from the ground on the plains can be seen by a man standing high enough, say 10 feet, for probably considerably more than 5 miles. A traptoreh, making less light, we will assume to show up for one mile. We will assume that the Hemileuca moths can see as well as man ?hen a trap torch would attract moths from a circle having a riidius of a mile, or from about 2000 acres. From what is known we may assume the males to travel 50 miles and the females 2.$)$ miles a night, berce the moths within that circle of nne mile radius are always charging, that is, if all were caught by the torch at a given time, the supply would be replenished 25 to 50 times respectively.

The cost of using a traptorch is not at all great, as a gallon of gasoline would run about all night, the other expense is for the anparatus and for the necessary attention which costs but 
listle after the outfit is once going. And the benefit derived would extend over many times the original 2000 acres, although, of course, the further away, the less is the benefit.

With so much material to draw from, for experimental tests water and kerosene in the bottom of the pail should be used and the insects be frequently laddled out. In the case of straight range work, however, the necessity of providing for a supply of water and kerosene to fall into must be done away vith, since with many moths falling in there would be soon a luyer of dead moths that would prevent the newcomers from falling into the water and kerosene and thus might enable them to fly out again. This trouble I would overcome by fixing at the top of the pail an inverted cone made out of tin, practically on the same lines as the cover of a spittoon. A milkstrainer of suitable size with the screen cut out will do. This, with the blast blowing down into the hole, would prevent any escape, and would also cremate the moths as fast as they accumulated ligh enough and thus make the whole combination automatic.

There is no good reason why this arrangement should not produce a benefit that would pay many times for the cost.

However, if investigations were to show that I am wrong, there is yet a very good chance to control the trouble with the torch. This is by using a blast as the clusters of eggs are hatching and, further, when the larvae have grown some and are clinging during the hot part of the day to some regetation to escape from the hot ground. On page 78 the author says that larvae placed on such hot ground "in some ceases would die before moving an inch.....", Thus between a lick from the torch and the hot ground there is not much chance for survival.

The onion is the favorite food plant of the orion thrips. But this insect feeds readily upon many other cultivate 1 and un"ultivated plants. For control on the onion the Burean of Ento- 
mology recommends nicotine-sulphate sprays. The thrips conceal themselves a good deal between the sheaths of the onion leaves, similar to the chinch bugs on corn. There are about 6 to 8 generations according to latitude. While young, these thurips are easily affected by the nicotine-sulphate spray. But the use

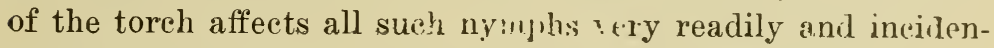
tally brings out the adults from their hiding places.

When the onions get ripor or wre inined, the thips luok for other food plants, plants of the cabbage and cucumber tribe being favorites. The Department of Agriculture advises not to plant any of these plants near onions. But ihen they are needed in any well regulated family and just the oprosite should $1: 0$ done, at least to a limitea extent. Enum wf these rorois should be planted to attract the thrips leaving the onions and the thrips being thus concentrated upon these plants can be kept down by frequent slight lickings with thr torch. These slight lickings are usually necessary anyway to kee! down eertain fungi affecting these plants. Late cucumbers suffer oft $\_n$ greatly from fungus and applications of both insecticides snd fungicides are difficult, but the plants of the cucumber tribe very readily take to treatment with the torch.

In as much as pearblight is spread through exudations on infested trees that are bcing sucked up by insects and then transferred into the sap of other trees by the piercing of the skin by these insects, I suggested in 1903 to the Department of Agriculture to make tests as to what would be the result, if these exudations were, at suitable intervals, be licked over with a flame from the torch. They said that it might be of some value. However, nothing was done.

If the use of a torch should be shown to be of no value in this case, I would consider that smearing the exudations over with some such matter as air slacked lime, or a mixture of it with clay, carbolated or otherwise made strongly disinfecting 
or not as tests may prove to be best, applied dry or, probably more successfully, in pasteform with a plasterer's trowel, would permit the tree to throw off the matter it wants to throw off, but would not permit the insect to have access to it. Of course, this paste after getting dry is quite liable to erack, due to evaporation as well as due to the growth of the tree, but these cracks it should be easy to fill up by dashing with a paste hrush or a suitable broom some more of the same stuff, in more liquid form, over the stuff already on.

To thus prevent pearblight, or what is also called fireblight, and control diseases of similar nature, work on covering up the exudations or the spots where they are breaking out must naturally be prompt for best results. Possibly a semiliquid smear applied with a pastebrush will prove to be best.

And, well, so it goes on through all the crops. While the old standard remedies have their place, there are cases where because of ripening fruit they cannot well be employed even if otherwise they be the most satisfactory for the insects and rungi then present.

vuring 1902 and 1903 I spent a great deal of time and money rrying to introduce the orch designed by me. Since its use involved a new principle, I knew at the outset that success, as rar as financial returns within a reasonable time were concernea, was dependent upon what position the Official Entomologists would take in regard to the use of heat thus applied. Being green, I thought I had a good chance.

The Department of Agriculture reported that they had used a torch on a cabbage heavily infested with lice, and with unsatisfactory results. Well what else could they expect?What else could they use and get beneficial results? The thing had gone beyond control unless heat or some spray were used in moderate stregth very often, which would make control, with the spray at least, improfitable. As a matter of fact, the De- 
partment recommended the picking off of infested leaves early in the game and I had, for successful treatment, required that the heat be allowed to play upon such leaves, or, rather, on all the leaves and without discrimination unless a plant is noticed to be heavily infested, and at an early stage, and as often as nay be necessary to control them well at an early stage. Nor would they make any further tests, or let some commercial grower try it for them.

But then the world moves. And the average farmer knows a good thing when he sees it. Thus it comes that you find in Entomology Bulletin No. 95, part III. page 38, issued Decemler 14th, 1911, treating on chinch bug investigations west of the Missippi river, in regard to getting rid of chinch bugs atter they have entered a cornfield and collected on the first 2 or 3 rows, that they can be gotten rid of in two ways, "by applying a gasoline torch and by spraying them with specially prepared solutions."

"The flaming torch is not altogether satisfactory on account of the liability of damaging the plants...... generally one blast will cause all the bugs to fall to the ground where they can be hurned.......several spraying materials can be used effecively ...... but most of these are injurious to the plants.'"

These sprays cost much more. With the torch only the outsice of the lowest leafsheaths is affected and the plants gruw along practically unharmed. The injury from the sprays is mnch more serious and much less easily overcome by the plant.

To prevent the bugs from reaching the cornfield as they micrate from ripening small grain, dust barriers and coal tar varriers are recommended. The chief objection to the first is ihat "often, during the migration, the bugs travel all night," hence are liable to get to your corn while you take a nap since this plan requires that the pulverizing "block must lie krpt in 
constant use, from early until late and sometimes well into the night." The coal tar barrier is "apparently costly and troublesome", the chief dependence being a sure enough adequate supply of tar and freedom from dust, as this would require that tine line of tar be renewed "quite often." As either plan is quite likely to prove defective, it would seem best to rely on the torch on the outset.

On pages 32 to 37 the authors point out that the chinch bugs hibernate chiefly on clump-forming grasses growing on waste land and in meadows and that burning these carefully over in the fall kills about 80 per cent of the hibernating bugs, due to the heat and subsequent exposure. But burning is wasteful. Mireover as hibernated bugs readily fly great distances to find a field of small grain in the spring, the work to be of ary noticeable value must be done by all the fiarmers in a neighborhood. Nature provided these dry tops for winter protection. Their destruction in the fall has a tendency to kill these useful grasses out and have their place taken by weeds. Talk abou; the high cost of living. These waste lands could be made to surport many flocks of sheep.

Since the Bureau of Entomology advocated the burning of the cottonstalks early in the fall-by about Oetoher 15th-- for many years past as the chief means of controlling the boll weevil, I showed as long ago as in my Circular No. 32, 1905 that according to the Department of Agriculture "the burning of a wheat stubble deprives the land of as much fertility as the producing of five crops of wheat." If this is so, the loss, of course, is not due to the little nitrogen that is in the stubble itself, but is due chiefly to the liberating of nitrogen and burning of humus in the soil by the heat.

On page 27 of Bulletin No. 139 of the Mississippi Agricultural Experiment Station you read: For controlling the boll- 
weevil "plow the stalks up, then rake them into windrows and as soon as they are dry burn them..... Do not allow the fire to spread as the burning of plants of any kind is a very bad practice. The soil is robbed of an immense amount of fertility every year by the burning over of our lands in Mississippi. Many good agricultural authorities even doubt the advisibility of recommending the burning of the cottonstalks as they claim that in time the burning off of this fertility will do more damage than the bollweevil.....'

The long and the short of this dispute is just this: A system of weevil control that allows of using only three-fifths of the season, as is at present the case, is a very bad system .

If you have all the fields infested so as to practically produce nothing by September 1st, sooner or later, it is undoubtedly best to cut off the plants - all the plants in all the fieldswhich is quite easily carried out, while plowing up is not at all easily carried out. This stops further eggdeposition, but as many larvae in infested squares and bolls would develop into adults if the plants were thus left, they, in this case, should be burned as there is no otler practical way to dispose of the infested squares and bolls.

Cutting off the plants along these lines, originally pointed out in my Circular No. 134, p. 4, answers every practical purpose. If the soil, during cultivation, has been thrown towards the plants rather than away from them, there will be few or iio sprouts. But if there are, there is nothing to show that the mere feeding, even on squares, prolongs the life of the adults to any great extent, if they, in the absence of food, can select shelter at will. And no egg ever laid in a square produced on such a sprout would have time to develop into an adult.

For proof I had shown in my Circulars No. 128, 129 and 130 that in cages placed in the open field weevils caged and depriv- 
ed of food October 26th gave with a mean average temperature of 51.9 degrees for the next seven days a survival of 25.12 per cent. A cage, along the same lines, started Novem $2 \mathrm{nd}$, with a mean for the first 7 days of 59.4 , gave a survival of 23.3 per cent; a cage started November 9 th, with a mean of 53.1 degrees gave a survival of 24.36 per cent and a cage started November 16 th with a mean of 55.3 gave a survival of 26.69 . On the other hand a cage started November 23rd with a mean of 70.31 degrees for the 7 next days showed a falling off to 12.67 per cent. The cause of this falling off was shown from the results of these and other cages to be due to lack of access to cool shelter when the temperature was high right after caging. That this is colrect is proved further by the result of the next cage starterl $N_{0}$ vember 30 th which with a mean of 55.9 degrees showed a survival of 29.7 per cent.

These results show that $I$ was right all along in riainins that weevils left uncaged would select, in the failure of finding food, cool places, and not dry stalks and loose litier in t'ie open field, especially if the rainfall is only 0.28 for the month of October as was then the case. This is further proved by a cage started in the woods Octobed 26th with Spanish moss on a stump for shelter which gave a survival of 43.69 per cent. lint the Bureau just simply could not see this evidence $\mathrm{Non}$ was any Secretary of Agriculture or Congressman willing to brimp their noses against it.

With the stalks cut off by September 1st and burrice $f$ or 5 days after, this, of course, means a quite different reanction than destruction by Octoher 15th which would dirive the weevils to the woods, where they could, with the temperature admittedly 10 to 15 degrees lower during the day, eas? ly sm. vive without food. If then the surviving hibernated weevils are watehed in the spring as they arrive at the cdge of the field 
and are promptly picked off as described in detail in m: Circular No. 137, they are so well kept in check, that, as iar as tile weevil is concerned, production will keep up till frost. The stalks, having been spaced close rather than far apart will then act as hibernating quarters to a certain extent and they should not be destroyed till hibernation is well under way. Then they can be chopped down with the stalk chopper and cleanly and safely deep buried, thus doing away with all burning.

In the case of the chinch bug, therefore, the use of the torch on the edge of the cornfield must be considered to he the buly really satisfactory course.

There were several torches sent to Experiment Stations and to Agricultural Papers doing experimental work of their own. One torch was sent to Orono, Me. and one to Berkeley, Calif. In both cases nothing of value was reported. They said the apparatus lad become out of order and that was sufficient reason to stop work. One torch was sent to the Cornell University. Ithacea, N. Y. Prof. Craig made some tests, principally for srcking insects on orchard trees. On the whole he did not condemn the use of heat outright, but said the apparatus is not effective enough to be used on fruit trees growing up to to feet high.

Now, that is on the whole true. It was equal to telling the manufacturers of bucket or barrel spray pumps that their apparatus were not powerful enough for such work. These have their uses where the poweroutfits cannot be used. The truth is the power spraying outfits were evolved from these smaller outfits. There is no real difficulty to construct a torch with a 20 to 50 gallon tank, one third full of gasoline, mounted way up on a tower as used with the power outfits to support one or more men, with as many leads of hose, pipe and burner as mav be desired. With the gasoline supply thus well raised there is no trouble keeping the burners going. For working in hop- 
yards, vineyards, or orange groves similar lower outfits can be made. The real question is whether or not the use of heat is economical and practical.

One torch was sent to the Illinois State Entomologist. He published a report claiming that the Michigan Station had in 1898, I believe, used a torch of the multiple type just described for work on the San Jose scale, but abandoned it as being too severe on the plants. Next the Director of the Texas Substation at Beeville was credited with having done some original work with a plumber's torch in, I believe, 1898. But from my intercourse with Mr. Winfree I had reason to believe that this was due to Mr. Winfree's efforts of selling torches in that part of the country for work on truck crops. Prof. Sanderson, then Texas State Entomologist, was reported with having used my torch on fallen cotton squares infested with boll weevil larvae lying on the ground with quite unsatisfactory results, which, of course, any sane man could foretell had to be as unsatisfactory as trying to sell a calf to a butcher while yet inside the cow. The report further stated that heat was applied to the leaves of a lilac plant heavily coated with spores, that the flame licked the spores off, but that after a few days new ones had cropped out, when every half ways educated farmer is supposed to know that the fungus works inside of the leaf, that the spores, in that case, are the resulting seeds, and their production must heep up till the fungus organization cannot produce any more. The report wound up with the statement, that while the use of heat may be practical to some extent, it cannot at present be recommended and-there the matter did rest, acd is resting now for all I know.

Neither Mr. Winfree nor myself was credited with having dore anything to point out tre possibilities of the use of heat in "ortrolling insests and furgi. I wrote to the Nieligan Station 
for any report they might have regarding the use of heat in 1898 or thereabouts. There was no reply.

Thus getting no encouragement from anywhere and getting it in the neck fair and foul from a few directions at the same time, I was unable to see that I had a ghost of a chance to keep from going broke if I kept up this work and stopped then and there to await some more propitious time for action.

One very good argument for that course was the fact that just then the boll weevil scare was at its height, Congress appropriating $\$ 250,000$ for one year's investigation work.

The Bureau of Entomology, at a very early stage, recommended as the chief means of control the universal cutting off of the food supply as early in the fall as the crop, or, rather, the bulk of it could be gathered.

Now, cutting off the food supply as soon as possible must, in a general way, be considered as being to some extent detrimental to the insect thus affected. It is a recommendation nearly as old as the hills and has been a favorite prescription for the control of insects affecting the cucumber tribe nearly quite as long. But every grower of these plants knows, that if he were to rely on it, it would not be worth while planting anything.

The Bureau first tried to prove their contention through apparently favorable results secured at Olivia, Texas by destroying the stalks on 400 acres during the first 10 days of October ard by destroying and keeping down all volunteer cotton. I at oree pointed out in my Circular No. 84, January 9th, 1908 and subsequently more in detail in my Circulars No. 85, 115 and 129, p. 4 that the weevils in that case had, since the nearest cotton patch was 15 miles away and the sea was on two sides, the surviving weevils, having scattered in search of food. but a whiff of a chance to find any cotton at all the followin spring, while, on the average, the cotton area is one-fifth of the 
total area of the affected States. The Bureau being unable to dispute this kept silent. Nor did I ever succeed to have the Secretary of Agriculture or the former Chairman of the House Committee on Agriculture stir them up.

The Bureau also claimed because of cage tests they made in 1906-07 that destruction of the stalks by October 15th would result in a survival of about 3 per cent of the adults then living. In the absence of details I pointed out in my Circular No. 10y, Sept. 21st, 1909, that destroying the food supply would mean to force them to hunt for such a supply, which in turn means that failing to find it, they would secrete themselves in cool places of their own selection. This suspicion that the Bureau in its tests had not given the weevils the choice of such selection was soon found to be well grounded, because Entomology, Bulletin No. 77 soon after came out and showed that the test cages were located in the open field, subject to the severe changes of heat and cold with no access for the weevils to places where the capillary attraction had not been disturbed. Even as it was, however, in eages managed along the same lines, Circular No. 31 of the Louisiana State Crop Pest Commission, p. 208, records a case of a weevil caged as early as September 28th, 1908 going without food from then, with the mean average temperature for the first 4 weeks, the most critical time, at 65.5 degrees, till June 9th 1909-255 days.

All efforts on my part to induce those charged with looking after the farmers' interests to force the Bureau to conduct tests that corresponded to normal conditions, that is in eages where the weevils have access to both such shelter as had been used before and also to shelter as furnished by rocks, grasses, weeds, bushes, stumps, on ground left undisturbed except for the fencing, and also in cages located in the woods, utterly failed. My contention is that destruction of the food supply once 
it is delayed till October 15 th should not be practiced at all, and that destruction of food supply to be of real value must be practiced much earlier. The proof for it and just what is wanted of the Bureau and of those charged with looking after them you find in my Circular No. 137. Thus far there was no action.

There was no lack of effort on my part to shake up the affected cotton growers. Since they seemed not to mind whether or not they got humbugged, I felt I should not press my case too hard. Now that the Argentine ant is trying to get intu the soup of these same people I thought it would be a good thing vo point out a thing or two.

The Department of Agriculture has always protested against any proposed legislation restricting its experiments. They are always hollering for more funds to carry on the work they claim the nation needs. In Bulletin No 5, of September 27th, I9I3, treating on the Southern corn root worm they complain on page I I about lack of fund's with which to make tests in an effort to find some practical measure to control this pest. Now this insect is closely related to the striped cucumber beetle which I lad pointed out ten years ago, is caught in the traptorch in large numbers. Hence it is very probable that the Southern corn root worm and many other related insects can be cheapest controlled by the traptorch And the Bureau had a chance to make tests along this line for ro years past. This traptorch ought to prove to be also the cheapest means of controlling certain weevils infesting clovers. The strawberry weevil might prove amenable to this treatment. " .... the 'green bug' in the South originates in spots in the grain fields ...." (Ent. Circular No 93.) And there is nothing at present that is or can be better for control than a blast from the torch. Then you have the Mexican conchucla starting on its way over the South. This insect is a more or less gregarious bug and considering its great variety of foodplants a blast from the torch is the most feasible means of control. And-well-and so on. But what can you 
do with men that refuse to point out the supposed mistakes they claim there exist in connection with my system of bollweevil control, when you do your level best to have the Secretary of Agriculture make them do it, and when Congress has given them for that work alone somewhat near two million dollars?

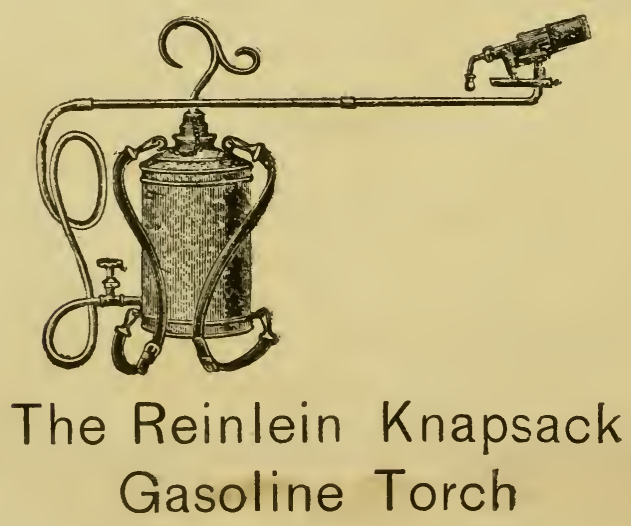

Patent No. 739,221; September 15th 1903

For description, see page 8 
Hollinger $\mathrm{pH} 8.5$ 


\section{LIBRARY OF CONGRESS}

LIBRARY OF CONGRESS

Miminarinimini

00008905290

Hollinger Corp. $\mathrm{pH} 8.5$ 